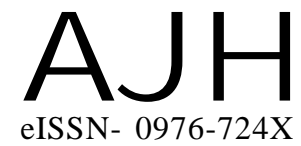

Received : 22.02.2017

Revised : 10.05.2017

Accepted : 23.05.2017

Members of the Research Forum

Associated Authors:

${ }^{1}$ Department of Horticulture, Faculty

of Agriculture, Annamamalai

University, Annamalai Nagar,

CHIDAMBARAM (T.N) INDIA

Email : kiransharaj@gmail.com

Author for correspondence :

D. ESAKKIMUTHU

Department of Horticulture, Faculty of

Agriculture, Annamamalai University,

Annamalai Nagar, CHIDAMBARAM

(T.N) INDIA

Email : mesakki50@gmail.com
THEASIAN JOURNAL OF HORTICULTURE

Volume 12 | Issue 1 | June, 2017| 132-135

Visit us -www.researchjournal.co.in

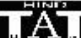

$\mathrm{S}^{*}$

RESEARCH PAPER

DOI : 10.15740/HAS/TAJH/12.1/132-135

\section{Effect of media on growth parameters of banana cV. POOVAN}

\section{ESAKKIMUTHU AND ARUMUGAM SHAKILA ${ }^{1}$}

ABSTRACT : The present investigation on effect of media on growth parameters of banana cv. POOVAN was carried out at the Department of Horticulture, Faculty of Agriculture, Annamalai University during 2014-2016. The experiment was conducted in Completely Randomized Design with 13 treatments in three replications. The treatments consisted of three growing media (FYM, Rice hull, Sawdust), two biofertilizers (Azospirillum and VAM) with sand alone as control. The results of the study revealed that the pseudostem height, pseudostem girth and number of leaves produced sucker ${ }^{-1}$ were favourably influenced by the treatment $\mathrm{T}_{7}(\mathrm{FYM}+\mathrm{VAM})$ followed by $\mathrm{T}_{10}(\mathrm{FYM}+$ Rice hull + VAM $)$. Regarding root production, $\mathrm{T}_{8}($ Rice hull + VAM $)$ was found to be the best treatment. Further more survival percentage of plants was higher in the treatments in which FYM was used as the regeneration medium along with VAM.

KEY WORDS : Growing media, Suckers, Biofertilizers, Growth parameters

HOW TO CITE THIS ARTICLE : Esakkimuthu, D. and Shakila, Arumugam (2017). Effect of media on growth parameters of banana cv. POOVAN. Asian J. Hort., 12(1) : 132-135, DOI : 10.15740/HAS/TAJH/ 12.1/132-135. 